Vol. 1, No. 1, Mei 2021 pp. 31-35

Jurnal IImiah Teknik Informatika, Elektronika dan Kontrol (Scientific Journal of Informatics, Electronics and Control Engineering)

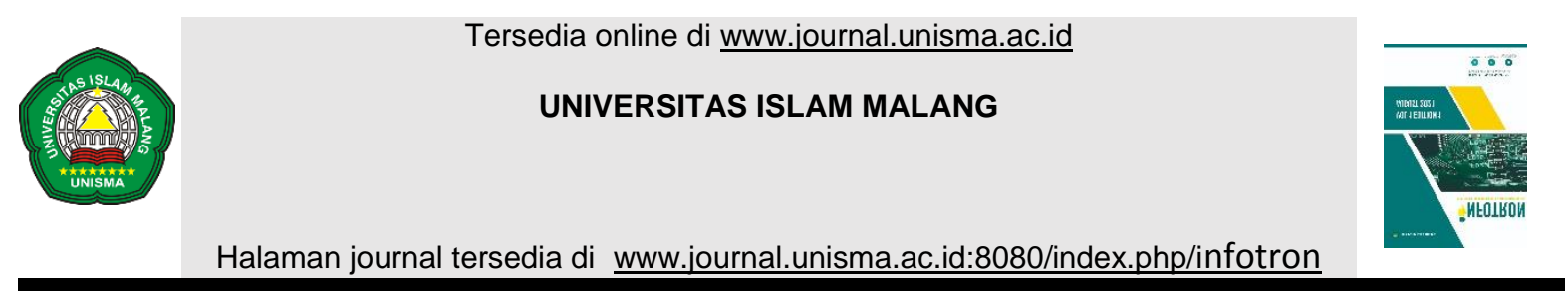

\title{
Uji Fungsional Sistem Pengukur Suhu Tubuh Berbasis Arduino Dengan Metode Blackbox Testing
}

\author{
Achmad Azrul Dean Haris a, Aris Sudaryanto b, Dwi Harini Sulistyawati c \\ a Teknik Informatika, Universitas 17 Agustus 1945 Surabaya, Surabaya, Indonesia \\ ${ }^{b}$ Teknik Informatika, Universitas 17 Agustus 1945 Surabaya, Surabaya, Indonesia \\ c Teknik Informatika, Universitas 17 Agustus 1945 Surabaya, Surabaya, Indonesia

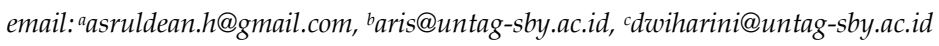

\begin{tabular}{l}
\hline INFORMASI \\
ARTIKEL \\
\hline \\
Sejarah artikel: \\
Received 6 Mei 2021 \\
Accepted 3 Juni 2021 \\
\hline
\end{tabular}

Kata kunci:

Thermometer tanpa kontak

Arduino

Blackbox Testing

\section{A B S T R A K}

Selama terjadi wabah Covid-19, thermometer menjadi barang yang sangat dibutuhkan masyarakat. Hal ini karena salah satu kondisi yang umum dialami oleh penderita Covid-19 adalah demam. Namun thermometer biasa juga kurang efektif digunakan, terutama jika untuk penggunaan dengan intensitas tinggi, seperti di tempat tempat layanan umum. Selain karena membutuhkan waktu lama dalam pemeriksaan suhu, thermometer biasa penggunaanya juga harus bersentuhan dengan kulit badan, padahal hal tersebut rawan menularkan virus. Maka solusi yang mungkin adalah sebuah sistem pengukur suhu tubuh tanpa kontak. Penelitian ini melakukan pengujian keandalan sistem pengukur suhu tubuh tanpa kontak menggunakan metode blackbox testing. Berdasarkan hasil pengujian yang telah dilakukan, fungsional sistem telah $100 \%$ bekerja dengan baik.

\section{Pendahuluan}

Sepanjang terjadinya wabah pandemi Covid-19 thermometer menjadi barang yang cukup banyak dicari, serta dengan sejumlah alat kesehatan lainnya. Bahkan sejumlah rumah sakit sempat mengalami kekurangan alat kesehatan [1]. Thermometer menjadi alat yang cukup vital selama pandemic, karena dapat dijadikan sebagai alat skrining awal akan Covid-19 yaitu demam, meskipun memang tidak dapat dijadikan sebagai alat diagnosis utama. Namun meskipun begitu, thermometer biasa masih belum cukup baik untuk penggunaan dengan intensitas tinggi. Hal ini karena pertama, thermometer biasa membutuhkan waktu dalam pengukuran suhu, kedua pengukuran suhu tubuh menggunakan thermometer biasanya harus bersentuhan kulit. Padahal kontak fisik cukup rawan dalam menularkan virus Covid-19. Untuk mengatasi permasalahan tersebut maka peneliti telah membuat sebuah sistem pengukur suhu tubuh tanpa kontak berbasis Arduino menggunakan sensor suhu infra merah MLX90614. Untuk mengetahui keandalan sistem yang telah dibuat, maka pada penelitian ini berfokus pada pengujian sistem menggunakan metode blackbox testing. 


\section{State of the Art}

Selain itu, penelitian lain dilakukan oleh Gusti Arya Dinata dengan judul "Rancang Bangun Alat Pengukur Suhu Tubuh Manusia Dengan Non-Contact Thermometer". System pada penelitian ini memang dapat mengukur suhu tubuh tanpa ada kontak, dan data bias disimpan. Akan tetapi penyimpanannya baru menggunakan EEPROM [2].

Penelitian lain yang sama sama menggunakan sensor MLX90614 adalah milik Irna Tri Yuniahastuti dengan judul "Contactless Thermometer sebagai Upaya Siaga Covid-19 di Universitas PGRI Madiun". Pada Penelitiannya, Irna mengukur suhu tubuh namun tanpa melakukan pembatasan pengguna, sehingga penggunanya bisa siapa saja dan tidak tercatat dengan baik [3].

Penelitian lainnya dilakukan oleh Heady Dianty dengan judul "Mendeteksi Suhu Tubuh Menggunakan Infrared Dan Arduno". Pada penelitian ini yang dilakukan hanya menampilkan data suhunya di Lcd-display tanpa menyimpan data hasil pengukuran [4].

Dalam hal penggunaan sensor ultrasonic, pada tahun 2020 peneliti pernah menggunakan juga sensor ultrasonic, namun untuk mendeteksi ketinggian permukaan air sungai sebagai sebuah sistem deteksi dini banjir. Kekurangan pada penelitian ini adalah, kondisi permukaan air sungai cenderung beriak atau tidak tenang, sehingga hasil pembacaan sensor ultrasonic juga berubah berubah [5].

Sedangkan penelitian lain terkait penggunaan sensor suhu, dilakukan oleh Rasyid Dwi Irsansyah pada tahun 2020. Rasyid menggunakan sensor suhu DHT-11 untuk mengukur suhu lingkungan pada tanaman cabai. Kekurangan dari penggunaan sensor suhu DHT-11 ini adalah respon yang cukup lama terhadap perubahan suhu [6].

\section{Method}

Sistem pengukur suhu tubuh ini pertama kali yang dilakukan adalah memeriksa apakah ada orang atau tidak, caranya dengan menggunakan sensor ultrasonic. Jika sensor ultrasonic mendeteksi halangan (ada pengguna didepan alat), maka selanjutnya system akan meminta pengguna untuk melakukan tapping RFID tag ke alat. Sebaliknya jika sensor ultrasonic tidak mendeteksi adanya halangan (tidak ada pengguna didepan alat) maka system tidak akan melakukan apa apa.

Selanjutnya system akan mendeteksi RFID tag yang ditempelkan pada alat. Jika RFID telah terdaftar dan dapat dikenali maka dapat berlanjut ke langkah selanjutnya. Sebaliknya jika RFID belum terdaftar dan tidak dapat dikenali maka system akan kembali pada tahap awal, yaitu mendeteksi keberadaan pengguna menggunakan sensor ultrasonic.

Tahap selanjutnya alat akan mengukur suhu tubuh dari pengguna tanpa kontak menggunakan sensor suhu MLX90614. Data suhu tubuh pengguna akan ditampilkan pada LCD display. Sistem juga akan mendeteksi suhu tubuh pengguna, jika kurang dari 38 derajat celcius maka berarti suhu normal, namun jika suhu lebih dari 38 derajat celcius maka berarti pengguna sedang demam dan sistem akan menyalakan buzzer. Terakhir, data pengguna, suhu tubuh, serta informasi waktu disimpan dalam database.

Untuk mengukur keandalan fungsional system, pada penelitian ini digunakan metode blackbox. 


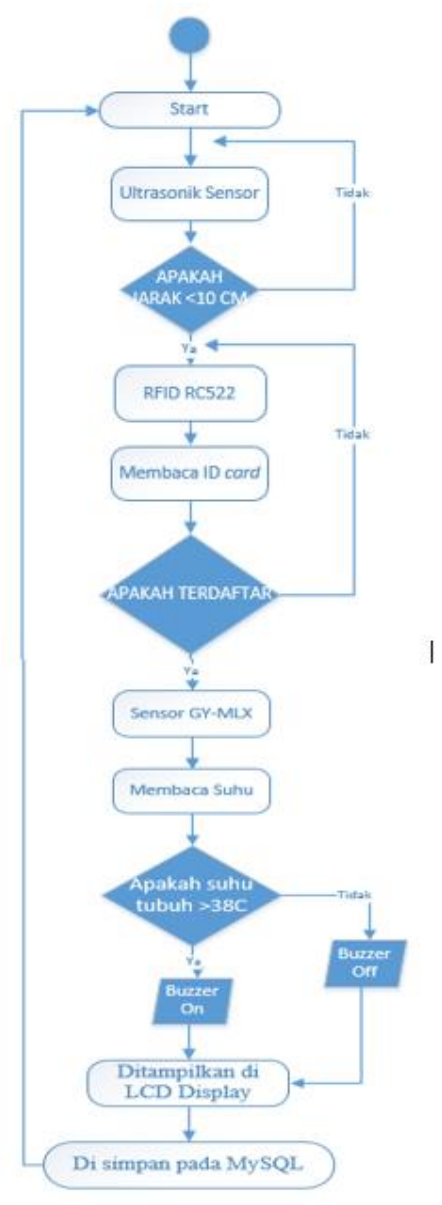

Gambar 1. Diagram alir system

\section{Hasil and Pembahasan}

Pengujian keseluruan alat bertujuan untuk memastikan apakah alat dapat berfungsi dengan baik mulai awal proses input sampai proses output.

Ada lima hal yang diuji menggunakan metode blackbox testing dalam penelitian ini, yaitu fungsi deteksi pengguna menggunakan sensor ultrasonic, fungsi pembacaan RFID tag, fungsi pengukuran suhu, serta fungsi penyimpanan data. Masing masing akan diuji coba dengan dua jenis masukan (input), kecuali fungsi penyimpanan data yang diuji dengan satu jenis masukan (input) saja. Fungsi deteksi pengguna diberi masukan dua jenis, yaitu jarak $<10 \mathrm{~cm}$ dan jarak $>10 \mathrm{~cm}$. Fungsi pembacaan RFID tag juga diberi dua jenis masukan yaitu RFID tag terdaftar dan RFID tag tidak terdaftar. Fungsi pembacaan suhu diberi masukan data suhu $<38$ derajat celcius dan data suhu $>38$ derajat celcius. Terakhir, fungsi penyimpanan data diuji dengan satu jenis data, yaitu data suhu yang terbaca oleh sensor.

Tabel 1. Hasil uji blackbox testing

\begin{tabular}{|c|c|c|c|c|c|c|}
\hline No. & Skenario Pengujian & Test Case & $\begin{array}{l}\text { Hasil yang } \\
\text { Diharapkan }\end{array}$ & $\begin{array}{c}\text { Hasil } \\
\text { Pengujian }\end{array}$ & Validitas & Prosentase \\
\hline \multirow{2}{*}{1} & \multirow{2}{*}{$\begin{array}{c}\text { Mendekatkan objek } \\
\text { pada sensor } \\
\text { Ultrasonik }\end{array}$} & jarak $<10 \mathrm{~cm}$ & $\begin{array}{l}\text { Objek terdeteksi } \\
\text { oleh sensor } \\
\text { ultrasonic }\end{array}$ & $\begin{array}{l}\text { Sesuai } \\
\text { harapan }\end{array}$ & Valid & $100 \%$ \\
\hline & & jarak $>10 \mathrm{~cm}$ & $\begin{array}{c}\text { Tidak terdeteksi } \\
\text { oleh sensor } \\
\text { ultrasonik }\end{array}$ & $\begin{array}{l}\text { Sesuai } \\
\text { harapan }\end{array}$ & Valid & $100 \%$ \\
\hline
\end{tabular}


Haris., A, A, D., et. al./INFOTRON 1 (1) 2021 pp. 31-35

\begin{tabular}{|c|c|c|c|c|c|c|}
\hline \multirow[t]{2}{*}{2} & $\begin{array}{c}\text { Melakukan } \\
\text { pembacaan kartu }\end{array}$ & Terdaftar & $\begin{array}{c}\text { Bisa mengakses } \\
\text { dan bisa } \\
\text { menggunakan } \\
\text { alat }\end{array}$ & $\begin{array}{c}\text { Sesuai } \\
\text { harapan }\end{array}$ & Valid & $100 \%$ \\
\hline & RFID & $\begin{array}{c}\text { Tidak } \\
\text { terdaftar }\end{array}$ & $\begin{array}{c}\text { Tidak bisa } \\
\text { menggunakan } \\
\text { alat }\end{array}$ & $\begin{array}{c}\text { Sesuai } \\
\text { harapan }\end{array}$ & Valid & $100 \%$ \\
\hline \multirow[b]{2}{*}{3} & & Suhu $<38^{\circ} \mathrm{C}$ & $\begin{array}{l}\text { Alarm buzzer } \\
\text { tidak berbunyi }\end{array}$ & $\begin{array}{c}\text { Sesuai } \\
\text { harapan }\end{array}$ & Valid & $100 \%$ \\
\hline & $\begin{array}{l}\text { Membaca suhu } \\
\text { dengan } \\
\text { menggunakan sensor } \\
\text { gy-mlx }\end{array}$ & Suhu $>38^{\circ} \mathrm{C}$ & $\begin{array}{l}\text { Alarm buzzer } \\
\text { berbunyi } \\
\text { memberi } \\
\text { peringatan } \\
\text { bahwa suhu } \\
\text { tidak normal }\end{array}$ & $\begin{array}{l}\text { Sesuai } \\
\text { harapan }\end{array}$ & Valid & $100 \%$ \\
\hline 4 & $\begin{array}{l}\text { Menyimpan data } \\
\text { hasil pengukuran } \\
\text { suhu }\end{array}$ & $\begin{array}{c}\text { Suhu yang } \\
\text { terbaca oleh } \\
\text { sensor MLX } \\
90614\end{array}$ & $\begin{array}{c}\text { Data dapat } \\
\text { tersimpan ke } \\
\text { dalam MySQL }\end{array}$ & $\begin{array}{c}\text { Sesuai } \\
\text { harapan }\end{array}$ & Valid & $100 \%$ \\
\hline & Rata rata total & & & & & $100 \%$ \\
\hline
\end{tabular}

Berdasarkan data pada Tabel 1 terlihat bawah seluruh fungsi berjalan baik 100\%. Fungsi deteksi pengguna menggunakan sensor ultrasonic $100 \%$ valid untuk masukan jarak $<10 \mathrm{~cm}$, juga $100 \%$ valid untuk masukan jarak $>10 \mathrm{~cm}$. Fungsi pembacaan RFID tag 100\% valid untuk masukan RFID tag terdaftar dan juga $100 \%$ valid untuk masukan RFID tag tidak terdaftar. Fungsi pembacaan suhu menggunakan sensor MLX90614 100\% valid baik untuk masukan data suhu <38 derajat celcius maupun masukan data suhu $>38$ derajat celcius. Terakhir, fungsi penyimpanan data juga 100\% valid dan dapat menyimpan data suhu yang terbaca oleh sensor.

\section{Kesimpulan dan Saran}

Berdasarkan pengujian yang telah dilakukan terhadap empat fungsi alat, yaitu fungsi deteksi keberadaan pengguna, fungsi pembacaan data RFID tag, fungsi pengukuran suhu tubuh, serta fungsi penyimpanan data, keseluruhan fungsi bekerja baik dengan nilai $100 \%$.

Selanjutnya untuk mendesain alat yang lebih baik lagi, menurut peneliti perlu dilakukan beberapa perbaikan, antara lain adalah desain alat perlu dibuat lebih praktis.

\section{Refrensi}

[1] "Pasien Covid-19 Kondisi Berat Meningkat, RS Kekurangan Alkes," 2021. https://www.cnbcindonesia.com/news/20210129145758-8-219688/pasien-covid-19-kondisiberat-meningkat-rs-kekurangan-alkes.

[2] D. R. Gusti Arya Dinata, Meilia Safitri, "Rancang Bangun Alat Pengukur Suhu Tubuh Manusia Dengan Non-Contact Thermometer," pp. 1-10, 2017.

[3] I. T. Yuniahastuti, I. Sunaryantiningsih, and B. Olanda, "Contactless Thermometer sebagai Upaya Siaga Covid-19 di Universitas PGRI Madiun," ELECTRA Electr. Eng. Artic., vol. 1, no. 1, p. 28, 2020, doi: 10.25273/electra.v1i1.7597.

[4] H. Dianty, "Mendeteksi Suhu Tubuh Menggunakan Infrared," J. Ilmu Komput., vol. 3, no. 3, pp. 5-9, 2020.

[5] A. Sudaryanto and I. Ariansyah, "PENGUJIAN SISTEM STATUS PADA ALAT DETEKSI DINI BANJIR SECARA REAL TIME," 2020, [Online]. Available: http://repository.untagsby.ac.id/4015/.

[6] Irsansyah and R. Dwi, "PENGUJIAN LOGIKA FUZZY PADA SISTEM MONITORING 
TANAMAN CABAI," 2020, [Online]. Available: http://repository.untagsby.ac.id/5928/9/JURNAL.pdf. 